\title{
A Study of Cropping System on Rice-Wheat Growth Parameter and Yield Attribute of Alkali Water and Gypsum Application
}

\author{
Chhote Lal Rawat ${ }^{1 *}$, Ravindra Kumar ${ }^{1}$ and Raj Kumar ${ }^{2}$ \\ ${ }^{1}$ Department of Soil Science and Agricultural Chemistry, C.S. Azad University of Agriculture \\ and Technology, Kanpur, India \\ ${ }^{2}$ Department of Soil Conservation and Water Management, C.S. Azad University of \\ Agriculture and Technology, Kanpur, India \\ *Corresponding author
}

A B S T R A C T

\begin{tabular}{|l|}
\hline K e y w o r d s \\
Soil application of \\
gypsum, Growth \\
parameter, Tillers, Plant \\
height, Panicle length, \\
$\begin{array}{l}\text { Sodic water and cropping } \\
\text { system }\end{array}$ \\
\hline Article Info \\
\hline $\begin{array}{l}\text { Accepted: } \\
\text { 17 January } 2018 \\
\text { Available Online: } \\
\text { 10 February } 2018\end{array}$ \\
\hline \hline
\end{tabular}

The experiment was conducted during 2015-2017 in kharif and rabi season on Crop Research Station, Nawabganj, C.S. Azad University of Agriculture and Technology, Kanpur to carried out the on rice and wheat crop of cropping system with seven treatments i,e.; Control (Sodic water) $\left(\mathrm{T}_{1}\right)$, Gypsum Beds Treatment of sodic waters $\left(\mathrm{T}_{2}\right)$, Soil Application of gypsum (25\% gypsum Requirement) $\left(\mathrm{T}_{3}\right)$, Soil application of gypsum (25\% $\mathrm{GR})+$ GBT of Sodic water $\left(\mathrm{T}_{4}\right)$, Soil application of gypsum (50\% GR) $\left(\mathrm{T}_{5}\right)$, Soil Application of gypsum $(50 \% \mathrm{GR})+\mathrm{GBT}$ of Sodic water $\left(\mathrm{T}_{6}\right)$ and Soil application of gypsum $(100 \% \mathrm{GR})\left(\mathrm{T}_{7}\right)$ in Randomized Block design (RBD) with four replications. The results showed higher growth parameter yield attributing i.e. tillers, plant height, panicle length, number of grain and test weight in rice were recorded $378,95.55 \mathrm{~cm}, 25.9 \mathrm{~cm}, 120$ and $33.83 \mathrm{~g}$ and wheat were recorded $378,95.55 \mathrm{~cm}, 25.9 \mathrm{~cm}, 120$ and $33.83 \mathrm{~g}\left(\mathrm{~T}_{6}\right)$ respectively with the application of (SA of gypsum (50\% GR) + GBT) of Sodic water in comparison to control $\left(\mathrm{T}_{1}\right)$. Application of these recommendation in Sodic water dominant area to gating maximum yield and maintain soil health it is also sustain crop production very profitable for marginal farmers.

\section{Introduction}

Irrigation water is one of the most critical but scare resources for agriculture production in arid and semi-arid regions of India. Major enhancement in agriculture productivity from these areas can be achieved through enhancement of this resource base with the rapid development of ground water and better rainwater management. Areas characterized by water scarcity are also usually underlain by aquifers of poor quality. Nevertheless, driven by the pressure to produce more, even the brackish ground waters are being increasingly diverted for irrigation. Indiscriminate use of poor quality waters in the absence of proper soil water-crop management practices pose grave risk to soil health and environment. Development of salinity, sodicity and toxicity problem in soil not only reduces crop productivity but also deteriorates the quality of produce and limit the choice of crop. Most of 
the time in black soils regions the effect generally become so severe that lands eventually go out of cultivation even at marginal levels of salinity/sodicity in irrigation water. The use of poor quality ground water is very dangerous and cannot be recommended without adopting safety measures otherwise it may produce irreparable loss to soil health. Possibilities have emerged to safely use of water.

India has been blessed with two major natural resources, relatively productive land and good reservoir of water resources. At the same time, India has one of the highest population density (382 people per $\mathrm{km}$ ) and population growth rate (2\% per year). Increased population (India 1200 million and U.P. 200 as per census 2011) pressures are expected to shrink per capita cultivable land further in the years to come. Most of the land areas in our country show evidence of degradation, affecting, thereby, the productive resource base. Out of total geographical area of 329 million hectare, 175 million hectare is considered as affected, in which sodic soils and saline soils including coastal areas account for 3.6 and 5.5 million hectare, respectively. The sodic soils are largely predominant in the Indo-Gangetic plains compassing the states of Punjab, Haryana, Utter Pradesh, part of Bihar and Rajasthan, part of black soil areas of Gujarat, Maharashtra, Karnataka, Andhra Pradesh and T.N. Isolated patches of sodic soils are also occur in some other states. In addition, with the advent of canal irrigation, salinity and sodicity is extending over large areas of fertile lands. Demand for finite water resources is increasing and with increase in population means land reclamation of poor and salt affected soil and then intensification of agriculture production system to food for the growing population. This means demand for irrigation water and agricultural chemicals will increase to produce more food resulting in the pollution of soil, water, air and other natural environments. Intensification of agriculture in India has increased soil salinity/sodicity due to poor water management practices, water logging due to poorly managed irrigation system. All these factors have added enormous stress on available land and water resources. Unless best irrigation and cropping management system including use of poor quality water are developed in agricultural watersheds to protect degrading land and water resources in India, social and food security.

Hunger (for food) keeps hunting India in the past and remains to do so in future unless it urgently rectify its (i) age old land (1864) laws, (ii) restrain from manmade deterioration and shrink in natural resources, (iii) check population growth to a sustainable level, and (iv) make agricultural a profitable venture. We cannot ask for increase in farm produce indefinitely. We need to revisit our policies those adversely influencing agriculture production at present keeping in view the future food requirement of the country in context of global linearization.

Present investigation falls under the preview of second aspect mentioned above and effort has been made to utilize sodic underground water for irrigation with suitable amendment techniques to boost crop production under sodic soils condition.

\section{Materials and Methods}

\section{Geography and climatic conditions}

The district Kanpur is a part of doab lying sandwiched between the river Ganga and Yamuna falling between the parallels of $25^{\circ}$ $25^{\prime}$ to $26^{\circ} 58^{\prime} \mathrm{N}$ latitude and $79^{\circ} 31^{\prime}$ to $80^{\circ} 34^{\prime}$ $\mathrm{E}$ longitude. Its gently slopes from NorthWest to South-East and it is located at an elevation of 125.9 meters above mean sea level. 


\section{Material and Experimental Techniques}

\section{Gypsum bed technology}

Conventionally, sodic hazards of sodic irrigation water is mitigated by applying and mixing uniformly the powdered gypsum in a leveled field and then flooding with fresh water, well before the sowing of crops. Relatively more economic and efficient technology known as "Gypsum bed technology" developed by CSSRI, Karnal, in which sodic water is made to pass through a chamber of gypsum and water dissolved calcium sulphate is applied to soil.

Gypsum chamber/bed is a brick - cement concrete chamber (Size $2.5 \mathrm{~m} \times 1.5 \mathrm{~m} \times 1 \mathrm{~m}$ ). This chamber is connected to water fall chamber to one side and to water channel the other side. A net of iron bars with mesh covered $(2 \mathrm{~mm} \times 2 \mathrm{~mm})$ is fitted at a height of $10 \mathrm{~cm}$ from the bottom of the bed on which the gypsum clods are filled up for $15 \mathrm{~cm}$ depth. This model is considered optimum for a well discharge of 4 liters per second and command area of 40 ha of land. Fresh gypsum clods are added to the gypsum bed before and during each irrigation to maintained $15 \mathrm{~cm}$ gypsum depth. Treated sodic water samples were collected during each irrigation and analysed for gypsum content. Gypsum dissolution for each irrigation was calculated by multiply gypsum content in treated sodic water with volume of sodic irrigation water. Similar observations were also reported by Gupta et al., (1994), Oster et al., (1999), Kaledhonkar (2003), Joshi and Narain (2004) and Gupta (2004).

\section{Analysis of soil and water}

In order to study the physico-chemical characteristics of soil, representative soil sample from a depth of $0-20 \mathrm{~cm}$ were collected. A composite sample was prepared from these primary soil samples. It was air dried and then oven dried at $105^{\circ} \mathrm{C}$ for estimation of moisture content. Soil sample were air dried ground to pass through $2.0 \mathrm{~mm}$ sieve and analysed for its physic- chemical characteristics. Sodic water samples both gypsum treated and untreated were collected and analysed for $\mathrm{pH}, \mathrm{EC}$, ionic composition and RSC value.

Soil and water samples were analyzed following procedure as described by Chopra and Kanwar (1976).

Soil texture (International pipette method), CEC (Neutral normal ammonium acetate method), gypsum requirement (EDTA or Versenate method using Erichrom black $T$ indicator), organic carbon (Wakleyand Black method), $\mathrm{pH}$ (digital $\mathrm{pH}$ meter), EC (digital conductivity meter), carbonate and bicarbonate (titrating with standard N/10 $\mathrm{H}_{2} \mathrm{SO}_{4}$ using phenolphthalein and methyl red indicator), chloride (titrating with standard solution of $\mathrm{AgNO}_{3}$ using potassium chromate. $\mathrm{K}_{2} \mathrm{CrO}_{4}$ as indicator), sulphate (turbidimetric method), Calcium and magnesium (versenate method using Erichrome black $\mathrm{T}$ indicator), calcium (versenate method using murexide indicator), sodium and potassium (Flame photo meter) were determined following standard procedures. Residual sodium carbonate (RSC) was determined by subtracting millie quivaents (meq) of $(\mathrm{Ca}+\mathrm{Mg})$ from milli equivalents of $\left(\mathrm{CO}_{3}+\mathrm{HCO}_{3}\right)$ and expressed as meq/l.

Result of studies on gypsum dissolution by sodic irrigation water through $15 \mathrm{~cm}$ gypsum bed (Table 1) indicated higher average rate of gypsum dissolution during kharif $(0.92 \mathrm{t}$ $\left.\mathrm{ha}^{-1}\right)$ in comparison to rabi $\left(0.81 \mathrm{t} \mathrm{ha}^{-1}\right)$ season. Annual average gypsum dissolution through sodic irrigation water found to be 1.73 $\mathrm{t} \mathrm{ha}^{-1}$ which correspond to $12.0 \%$ gypsum requirement 


\section{Treatments Details}

Control (Sodic water)

$\mathbf{T}_{1}$

Gypsum bed $(15 \mathrm{~cm})$ treatment (GBT) of sodic water

$\mathbf{T}_{2}$

Soil application (SA) of gypsum (25\% GR)

$\mathbf{T}_{3}$

Soil application (SA) of gypsum $(25 \% \mathrm{GR})+$ gypsum bed $(15 \mathrm{~cm})$

$\mathbf{T}_{4}$

treatment (GBT) of sodic water

Soil application (SA) of gypsum (50\% GR)

$\mathbf{T}_{5}$

Soil application (SA) of gypsum $(50 \% \mathrm{GR})+$ gypsum bed $(15 \mathrm{~cm})$

T6

treatment (GBT) of sodic water

Soil application (SA) of gypsum (100\% GR)

$\mathbf{T}_{7}$

Table.1 Gypsum dissolutions (t/ha) by sodic irrigation water through gypsum bed $(15 \mathrm{~cm})$

\begin{tabular}{|c|c|c|c|c|}
\hline Year & Kharif & Rabi & Total & Cumulative \\
\hline $2012-13$ & 0.93 & 0.72 & $1.65(11.4)$ & $1.65(11.4)$ \\
\hline $2013-14$ & 0.90 & 0.88 & $1.78(12.3)$ & $3.43(23.8)$ \\
\hline $2014-15$ & 0.88 & 0.89 & $1.77(12.2)$ & $5.20(36.1)$ \\
\hline $2015-16$ & 1.04 & 0.75 & $1.79(12.4)$ & $6.99(48.2)$ \\
\hline $2016-17$ & 0.85 & 0.82 & $1.67(11.5)$ & $8.66(60.0)$ \\
\hline Total (5 years) & 4.60 & 4.06 & - & - \\
\hline
\end{tabular}

Figure in parenthesis indicate \% GR

Table.2 Change in ionic composition of sodic waters as a result of gypsum $15 \mathrm{~cm}$ gypsum bed treatment

\begin{tabular}{|l|c|c|c|c|c|c|}
\hline Treatment & \multicolumn{4}{|c|}{ Anion $(\mathbf{m e q} / \mathbf{l})$} & \multicolumn{2}{c|}{ Cation (meq/I) } \\
\cline { 2 - 8 } & $\mathbf{C O}_{\mathbf{3}}$ & $\mathbf{H C O}_{\mathbf{3}}$ & $\mathbf{C l}$ & $\mathbf{S O}_{\mathbf{4}}$ & $\mathbf{C a}+\mathbf{M g}$ & $\mathbf{N a}+\mathbf{K}$ \\
\hline Untreated & Nil & 10.65 & 0.75 & 0.47 & 1.82 & 9.65 \\
\hline Treated & Nil & 10.13 & 0.92 & 3.57 & 6.12 & 8.27 \\
\hline Change & & & & & & - \\
\hline$(+)$ & - & - & 0.17 & 3.10 & 4.30 & 1.38 \\
\hline$(-)$ & - & 0.52 & - & - & - & \\
\hline
\end{tabular}

Table.3 Change in $\mathrm{pH}, \mathrm{EC}$ and RSC values of sodic waters as result of gypsum bed $15 \mathrm{~cm}$ treatment

\begin{tabular}{|l|c|c|c|}
\hline Treatment & $\mathbf{p H}$ & $\mathbf{E C}\left(\mathbf{d S m}^{\mathbf{- 1}}\right)$ & $\mathbf{R S C}\left(\mathbf{m e q}^{\mathbf{- 1}}\right)$ \\
\hline Untreated & 8.25 & 1.19 & 8.75 \\
\hline Treated & 7.84 & 1.47 & 4.02 \\
\hline Change & & & - \\
\hline$(+)$ & - & 0.28 & 4.73 \\
\hline$(-)$ & 0.41 & - & \\
\hline
\end{tabular}


Table.4 Effect of treatments on grain and straw yield of rice $\left(\mathrm{q} \mathrm{ha}^{-1}\right)$

\begin{tabular}{|c|c|c|c|c|c|c|c|}
\hline Treatment & $\begin{array}{l}\text { Grain yield } \\
\text { q ha }\end{array}$ & $\begin{array}{l}\text { Straw yield } \\
\text { q ha }\end{array}$ & Tillers/m² & $\begin{array}{l}\text { Plant height } \\
(\mathrm{cm})\end{array}$ & $\begin{array}{l}\text { Panicle } \\
\text { length }\end{array}$ & $\begin{array}{l}\text { No. of grain/ } \\
\text { ear }\end{array}$ & $\begin{array}{l}\text { Test weight } \\
\text { (g) }\end{array}$ \\
\hline Control (Sodic water) & 21.75 & 25.06 & 285 & 78.27 & 16.4 & 95 & 23.10 \\
\hline GBT of sodic water & 30.75 & 35.14 & 323 & 84.25 & 21.4 & 105 & 27.82 \\
\hline SA of gypsum (25\% GR) & 28.47 & 32.82 & 305 & 80.66 & 19.0 & 100 & 26.51 \\
\hline $\begin{array}{l}\text { SA of gypsum }(25 \% \text { GR })+\text { GBT of sodic } \\
\text { water }\end{array}$ & 33.39 & 36.35 & 354 & 89.72 & 24.1 & 115 & 29.00 \\
\hline SA of gypsum (50\% GR) & 33.25 & 37.88 & 345 & 86.72 & 23.3 & 111 & 28.10 \\
\hline $\begin{array}{l}\text { SA of gypsum }(50 \% \text { GR })+\text { GBT of sodic } \\
\text { water }\end{array}$ & 47.41 & 54.78 & 378 & 95.55 & 25.9 & 120 & 33.83 \\
\hline SA of gypsum (100\% GR) & 44.41 & 51.26 & 360 & 91.23 & 24.7 & 117 & 31.55 \\
\hline
\end{tabular}

Table.5 Effect of treatments on grain and straw yield of wheat $\left(\mathrm{q} \mathrm{ha}^{-1}\right)$

\begin{tabular}{|c|c|c|c|c|c|c|c|}
\hline Treatment & $\begin{array}{l}\text { Grain yield } \\
\qquad \mathbf{q} \mathbf{h a}^{-1}\end{array}$ & $\begin{array}{c}\text { Straw } \\
\text { yield } \\
\text { q ha }\end{array}$ & Tillers $/ \mathrm{m}^{2}$ & $\begin{array}{l}\text { Plant height } \\
\text { (cm) }\end{array}$ & $\begin{array}{c}\text { Panicle } \\
\text { length }\end{array}$ & $\begin{array}{l}\text { No. of } \\
\text { grain/ } \\
\text { ear }\end{array}$ & $\begin{array}{c}\text { Test weight } \\
\text { (g) }\end{array}$ \\
\hline Control (Sodic water) & 15.54 & 18.38 & 401.0 & 73.2 & 7.3 & 37.3 & 30.20 \\
\hline GBT of sodic water & 23.97 & 27.90 & 436.5 & 78.4 & 7.9 & 40.1 & 32.70 \\
\hline SA of gypsum (25\% GR) & 21.69 & 25.88 & 417.7 & 76.3 & 7.5 & 39.5 & 30.40 \\
\hline $\begin{array}{l}\text { SA of gypsum }(25 \% \mathrm{GR})+\mathrm{GBT} \text { of sodic } \\
\text { water }\end{array}$ & 31.05 & 35.57 & 436.8 & 84.3 & 8.6 & 45.7 & 38.35 \\
\hline SA of gypsum (50\% GR) & 29.76 & 34.86 & 432.0 & 81.2 & 8.2 & 43.8 & 36.30 \\
\hline $\begin{array}{l}\text { SA of gypsum }(50 \% \text { GR })+\text { GBT of sodic } \\
\text { water }\end{array}$ & 38.43 & 43.63 & 450.5 & 87.7 & 8.8 & 50.9 & 40.40 \\
\hline SA of gypsum (100\% GR) & 36.78 & 41.39 & 444.3 & 85.2 & 8.8 & 48.4 & 39.94 \\
\hline
\end{tabular}


Table.6 Changes in chemical characteristics of soil $(0-20 \mathrm{~cm})$ as affected by the treatments after 5 years

\begin{tabular}{|l|}
\hline Treatments \\
\hline Control (Sodic water) \\
\hline GBT of sodic water \\
\hline SA of gypsum $(25 \% \mathrm{GR})$ \\
\hline SA of gypsum $(25 \% \mathrm{GR})+$ GBT of sodic water \\
\hline SA of gypsum $(\mathbf{5 0 \%} \mathbf{G R})$ \\
\hline SA of gypsum $(\mathbf{5 0 \%} \mathbf{G R})+$ GBT of sodic water \\
\hline SA of gypsum $(\mathbf{1 0 0} \% \mathrm{GR})$ \\
\hline Initial values \\
\hline
\end{tabular}

Change in chemical composition in sodic water

Studies on Ionic composition of untreated and gypsum bed treated sodic irrigation water (Table 2) revealed absence of carbonate in sodic irrigation water but rich in bicarbonate (10.65 meq/l) with relatively very less amount of chloride $\left(0.75 \mathrm{meq}^{-1}\right)$ and sulphate $(0.47$ meq $\left.1^{-1}\right)$ anions. Sodium and potassium were the dominant cations $\left(9.65 \mathrm{meq} \mathrm{l}^{-1}\right)$ in untreated sodic irrigation water that contains relatively less amount of $\mathrm{Ca}$ and $\mathrm{Mg}$ ion (1.82 meq $1^{-1}$ ).

Gypsum bed treatment of sodic irrigation water reduced bicarbonate and sodium ions content by 0.52 and $1.38 \mathrm{meq}^{-1}$, respectively with considerable increase in sulphate (3.10 meq $1^{-1}$ ) and calcium (4.30 meq $1^{-1}$ ) ions. Similar response of rice-wheat system to sodic water irrigation (Choudhary et al., 2006, Sharma et al., 2006)

Considerable changes in $\mathrm{pH}, \mathrm{EC}$ and RSC (Residual sodium carbonate) of sodic irrigation water were recorded due to gypsum bed treatment (Table 3).

RSC and $\mathrm{pH}$ of sodic water reduced from 8.75 to $4.02(\mathrm{meq} / \mathrm{l})(54.1 \%)$ and 8.25 to 7.84 , respectively. whereas EC increased from 1.19 to $1.47\left(\mathrm{dSm}^{-1}\right)$

\begin{tabular}{|c|c|c|}
\hline $\mathbf{p H}$ & $\mathbf{E C}\left(\mathbf{d S m}^{-\mathbf{1}}\right)$ & $\mathbf{E S P}$ \\
\hline 10.02 & 2.83 & 66.15 \\
\hline 8.42 & 2.12 & 35.55 \\
\hline 8.64 & 2.17 & 50.27 \\
\hline 8.57 & 2.07 & 35.12 \\
\hline 8.25 & 1.52 & 25.22 \\
\hline 8.01 & 1.87 & 20.00 \\
\hline 8.17 & 1.15 & 27.24 \\
\hline 9.55 & 2.42 & 57.10 \\
\hline
\end{tabular}

\section{Yield of rice crop}

The soil application of gypsum alone and in combination with gypsum dissolution through $15 \mathrm{~cm}$ gypsum bed on average yield of rice (Table 4) revealed that the maximum yield of grain and straw was recorded as 47.41and $54.78 \mathrm{qha}^{-1}$, respectively with the application of gypsum $(50 \% \mathrm{GR})+$ gypsum bed of sodic water treatment followed by soil application of gypsum (100\%GR), and lowest yield of grain (21.75 $\left.\mathrm{qha}^{-1}\right)$ and Straw (25.00qha $\left.{ }^{-1}\right)$ was obtained from untreated plots. The yield was at par with the SA of gypsum $(25 \%$ GR) + GBT of sodic water, SA of gypsum $(50 \%$ GR) and GBT of sodic water. The gypsum application either through dissolution or soil enhanced yield of grain (65.2) and straw (66.9) was recorded over control untreated in rice crop. Similar Joshi and Narain (2004)

\section{Yield attributing characters}

The maximum productive tillers, plant height, panicle length, number of grain and test weight were recorded 378, $95.55 \mathrm{~cm}, 25.9$ $\mathrm{cm}, 120$ and $33.83 \mathrm{~g}$ respectively with the application of gypsum (50\%GR) + gypsum bed of sodic water treatment followed by soil application of gypsum (100\%GR),SA of gypsum $(25 \%$ GR) + GBT of sodic water and SA of gypsum (50\% GR), while the minimum productive tillers, plant height, panicle length, 
number of grain and test weight were recorded in control plots. Similar to Joshi and Narain (2004) and Vladimirovha (2004). The soil application of gypsum along with gypsum bed treatment of sodic water significantly improved the yield attributed characters compared to soil application of gypsum alone (Table 4).

\section{Yield of wheat crop}

Treatments effect as evident from the graded doses of soil applied gypsum alone and in combination with gypsum dissolution through gypsum bed on yield of wheat (Table 5) revealed that the maximum average yield of grain and straw was recorded as 38.43 and $43.63 \mathrm{qha}^{-1}$, respectively with the application of gypsum $(50 \% \mathrm{GR})+$ gypsum bed of sodic water treatment followed by soil application of gypsum $(100 \% \mathrm{GR})$, and minimum yield of grain (15.45 $\left.\mathrm{qha}^{-1}\right)$ and straw (18.30qha $\left.{ }^{-1}\right)$ was received from control treatment. The yields were at par with the SA of gypsum $(25 \% \mathrm{GR})$ + GBT of sodic water, SA of gypsum (50\% GR) and GBT of sodic water. The gypsum application either through dissolution or soil enhanced yield of grain $(68 \%)$ and Straw $(72 \%)$ was recorded over control untreated plots in wheat crop. (Levy et al., 1998, Minhas et al., 1999, Oster et al., 1999)

\section{Yield attributing characters}

The maximum productive tillers, plant high, panicle length, number of grain and test weight were recorded $378,95.55 \mathrm{~cm}, 25.9 \mathrm{~cm}$, 120 and $33.83 \mathrm{~g}$ respectively with the applications of gypsum (50\%GR) + gypsum bed of sodic water treatment followed by soil application of gypsum (100\%GR) (Aydemir and Najjar, 2005). The soil application of gypsum along with gypsum bed treatment of sodic water significantly improved the yield attributed characters compared to soil application of gypsum alone (Table 5).

\section{Changes in physico-chemical properties of soils}

Changes in physico-chemical properties of surface soil $(0-20 \mathrm{~cm})$ due to implementation of treatments for five years (Table 6) revealed that sodic water irrigation (control) considerably raise the value of $\mathrm{pH}, \mathrm{EC}$ and ESP of soil to $10.02,2.83 \mathrm{dSm}^{-1}$ and 66.15 , respectively from the corresponding initial values of $9.55,2.42 \mathrm{dSm}^{-1}$ and 57.10. Application of gypsum either through gypsum bed or soil significantly reduced soil $\mathrm{pH}, \mathrm{EC}$ and ESP. Sodic water irrigation through gypsum dissolution for five years reduced surface soil pH, EC an ESP to 8.42,4.25 dSm ${ }^{1}$ and 33.55 from corresponding initial values of 9.55,2.42 $\mathrm{dSm}^{-1}$ and 57.10, respectively. One time soil application of gypsum @ 50\% GR along with gypsum bed treatment of sodic irrigation water was found to be most effective in reducing soil $\mathrm{pH}$ (from 9.55 to 8.01), EC (from 2.42 to $1.15 \mathrm{dSm}^{-1}$ ) in comparison to the sole soil application of gypsum @ 50 or $100 \%$ GR and any other treatment combinations.

Keeping the mandate of the experiment initial at Crop Research Station, Nawabgang, Kanpur, it was concluded that the Soil application (SA) of gypsum (50\% GR) + gypsum bed $(15 \mathrm{~cm})$ treatment $(\mathrm{GBT})$ of sodic water treatments superior amongst all other treatments. The soil application of gypsum (100\% GR) treatment also shows good effect, but the response is at par. In this regard, it is evident that the RSC value 8.75 shows remarkable changes when water passed through $15 \mathrm{~cm}$ gypsum bed. The remarkable change in ionic composition was also observed. The $\mathrm{pH}$ value falls from initial value 9.55 to 8.01. Similarly, all other values viz. EC and ESP shows change their initial value $2.42 \mathrm{dSm}^{-1}$ and 57.10 to $1.87 \mathrm{dSm}^{-1}$ and 20.00. The same trend was also observed in yield potential. 


\section{References}

Abrol, I. P. Gaul, B.L. and Acharya, C.L. (1975). Efficient water Management key to source in alkali soil. Indian Farming, 25 (4): 15-17.

Abrol, I.P., Saha, A.K. and Acharya, C.L. (1978).Effect of exchangeable Sodium on some soil physical properties. Journal Indian Society of Soil Science, 26: 98-105.

Acharya, C.L. and., Sandhu, S.S. and Aborl, I.P. (1979).Effect of exchangeable Sodium on the rate and pattern of water uptake by Rai (Brassica juncea) in the field. Agron, Journal, 125: 36-41.

Acharya, and Abrol (1978). Exchangeable Na and soil water behaviour in Sodic and adjacent normal soil. J. Indian Society of Soil Science, 23: 391-401

Acharya, C.L. and Aborl, I.P. (1978).Exchangeable $\mathrm{Na}$ and soil water behavior under field condition. Soil Science, 125: 310-319

Amnal, U.B., Mahendra, P.P. and Arunachalam, G. (2001). Management high Irrigation water for growing crop, International Journal of Agriculture and biology, 3 (3): 312-315.

Anonymous (2000). Indian Agriculture in Brief, 27 edition, agriculture statistics Division Directorate of Economics and statistics Department of Agriculture and co-operation ministry of Agriculture,

Chaudhan, R.P.S., Singh, B.D., Singh, R.K. and Singh, V.P. (1999). Strategic nutrient management for sustained rice production in sodic soil, Fertil. News, 44 (8):13-26.

Chaudhary, O.P., Gurleenkaur and Benbi, D.K. (2006). Alternating irrigation with canal water and sodic water maintained soil sodium saturation at relatively low levels and helped. Experimental Agriculture, 25: 199-205.

Gharaiben, M. A. Eltaif, N.I. and Shunner,
O.F. (2009).Leaching and reclamations of calcrious saline-sodice soil by moderately saline and moderate SAR water using gypsum and calcium chloride, 713-719.

Gharaiben, M. A., Eltaif, N.I. and Shroan, S.H. (2010). Reclamation of calcareous saline-sodic soil using phosphoric acid and product. Gypsum, 26 (2):141-148.

Kumar Ravindra and Pal Samir (2009). Impact of change in cardinal temperature on growth and yield of rice and wheat. Ann. Pl. Soil Res. 11 (2):8082.

Kumar, P., Singh, A. K., Singh, A. and Singh, S. K. (2012). Efficacy of different amendment for the reclamation of sodic soils. Tchnofam 1(1):9-11.

Kumar, R, Singh. A, Kumar. G and Pandey S.N. (2016) Comparative Effect of Gypsum and Phosphogypsum on Crops Irrigated with alkali water under Sodic soil conditions. Environment and ecology, 34 (4B): 2212-2216.

Kumar, R. Tripathi, B. N, Kumar, V. and Panday, S.N (2012).Sustainabl production of parlmillt and sunflower undr alkali watrirrigatd conditions. Tachnofam- A. J. of M. AdvancRsarch 1(2): 91-94.

Pal Samir, Kumar R, Awasthi N., Tripathi G.S. and Katiyar P.S. (2010). Studies on relative efficiency gypsum dissolution and application in reaclamation of sodic soil for high productivity. p-21.

Pazhanivelan, S. Maricigthan, A.R. and Mohammed Haoon (2004). Conjunctive use of canal and sodic water for rice based cropping system in delta zone. Department of Crop management ADAC \& RI, Tiruchirapalli, Tamilnadu India.

Rajkumar, Ahuja, R. L, Singh, N. I. And Ghabru, S. K. (1994). Occurrence of sodic soil at different geomorphic location and climate in Satlej-Yamuna 
divide. Journal of the Indian Society of Soil Sciecne, 42 (1): 219-228

Rajput, S.G. and Polara, K.B. (2013). Evaluation of quality of irrigation water in coastal Bhavnagar district of Saurashtra region (Gujarat).Journal of the Indian society of soil science, Vol. 61, NO. 1, pp 34-37.

Roa, D.L.N. and Battra, L. (1983).Ammoniam volatilization from applied Nitrogen in alkali soils. Plant and Soil, 70:219-228.

Shainberg, I.M.E., Summer, W.P, Miller, M.P.W. and Farina, M. V. (1980). Use gypsum on soil. A Review Adv. Soil Science, 91-112.

Sharma, D.R., Minhas, P.S. and Sharma, D. K. (2001). Response of rice-wheat to sodic water irrigation and gypsum application, Journal Indian Society of Soil Science 49: 324-327.

Sharma, G.K., Chnipa, B.R. and Kantholiya (2004). Reported that sodicity hazards as well as high boron toxicity of irrigation water can be mitigated,
Journal Indian Society of Soil Science, 39: 537-541

Singh, M.V., Chhabra, R. and Aborl, I.P. (1987). Interaction between application of gypsum and zinc sulphate on the yield and chemical Composition of rice grown on an alkali soil. Journal of Agriculture Science Cambridge, 108 275-279.

Singh. D. and Tripathi, R.S. (2004). The study of alternating crop production plan in Haryana, CSSRI Karnal, India

Yadav, j. S., Metha, S.S. and Indaria, S. C. (2008). Impact of depth of sodic water irrigation and gypsum level of physicchemical properties of soil. Environment and Ecology, 26 (4A): 1795-1798.

Yadav, S.S., Saini J., Sharma, S.K. and Tikkoo A.(2013).Effect of sodic water Sprinkler irrigation depth and gypsum level on yield and mineral composition of wheat. Journal of Indian Society of Soil Science, Vol. 61, No. 2, pp 89-93.

\section{How to cite this article:}

Chhote Lal Rawat, Ravindra Kumar and Raj Kumar. 2018. A Study of Cropping System on Rice-Wheat Growth Parameter and Yield Attribute of Alkali Water and Gypsum Application. Int.J.Curr.Microbiol.App.Sci. 7(02): 1890-1898. doi: https://doi.org/10.20546/ijcmas.2018.702.228 